\title{
Editorial
}

\section{Hard questions, big challenges}

\section{Kelley Moult and Diane Jefthas}

kelley.moult@uct.ac.za

diane.jefthas@uct.ac.za

http://dx.doi.org/10.17159/2413-3108/2018/i65a5612

Hard questions, big challenges - the articles in this edition of the South African Crime Quarterly (SACQ) are a vivid illustration of the ways that South Africa's enduring problems remain perennially, persistently present. Andrew Faull pointed out in his editorial of a year ago (SACQ, September 2017) that South Africa's democratic gains were under threat from a number of quarters: commercial crime, state capture, collusion and abuse. A year on, some of these issues may feel a little like old news, as the reporting cycle (or possibly more accurately, our attention) has moved on from the \#Guptaleaks to questions of land, expropriations, elections and, perhaps most uncomfortably, sexual harassment.

Certainly, these problems are not new. The period since our last edition marked the sixth anniversary of the Marikana massacre, which took place on 16 August 2012, where 34 platinum miners who were on strike for better wages and improved living conditions were shot and killed by South African Police Service (SAPS) members. Six years on from the tragic events of that Thursday and there are still critical questions about who gave the order to shoot to kill at Marikana and consequently, who from the SAPS will be held accountable for what transpired. A commission of inquiry into the massacre, chaired by Judge lan Farlam, released its report in June 2015, finding that there should be additional investigation (and possible prosecution) by the National Prosecuting Authority (NPA) into those responsible for the killings - both police and strikers.

Sexual harassment in the workplace has been highlighted by feminist scholars, including criminologists, for at least four decades. It is also not a uniquely South African affliction, as the global \#MeToo movement attests. However, despite a progressive enabling legislative framework and significant policy attention early in our democracy, sexual harassment (and sexual offences more broadly) remains one of the country's pervasive, and silent, silencing scourges. Recent events have brought public scrutiny of the ways in which South African society tolerates this patriarchal exercise of power over women. We have watched as vaunted businesses, trusted civil society organisations and their leaders - those customarily lauded for speaking truth to power - have been accused and vilified as perpetrators, enablers and silencers. Cleavages have opened up as the backlash against the outing of these behaviours has taken hold: shifting blame onto the survivor, decontextualising their experiences, creating false equivalences between the systematic harassment of women and instances of women who sexually harass men, and holding up flawed disciplinary processes as impartial and fair. ${ }^{1}$ Conversations are happening around the country on what the appropriate response is. 
Perhaps in a year we will reflect on these as moments passed; as little more than poignant anniversaries. Hopefully not. Rather, we should use these opportunities to challenge our democracy to live up to its promise - by owning up to the vulnerability of victims in our country, to the insecurity of our children, to the tenuous safety of communities, to the enormously compromised position of many of our workers. The articles in this edition of SACQ focus the research spotlight on a number of these issues, filling gaps in our empirical understanding of these 'sticky problems': the events at Marikana Scene 2, bank associated robbery, sentencing in sexual grooming cases where complainants are under the age of 16 , and the use of illegally-obtained evidence under the proposed Traditional Courts Bill. These articles build on conversations in the field - including on the pages of $S A C Q$ - about gaps in policy and legislation, implementation, research and knowledge.

\section{This issue}

David Bruce presents an analysis of statements from the injured and arrested strikers taken by the Independent Police Investigative Directorate in the five days immediately after the Scene 2 massacre at Marikana at which 17 of the fatal shootings took place. By examining data from the contents of these statements, as well as the circumstances in which they were taken, the article interrogates the assertion that 'strikers were shot by police while surrendering or injured at Scene 2'.2 Bruce argues that, taken as a whole, the statements are a reliable source that suggests that some of the strikers at Scene 2 where indeed shot while surrendering.

Robert Doya Nanima extends the conversation on the latest version of the proposed Traditional Courts Bill (TCB), analysing the admission of evidence obtained through human rights violations. Nanima reviews the current Bill, and reflects on the challenges that arise with regard to evidence obtained in this way, discussing the practical difficulties of applying section 35(5) of the Constitution of the Republic of South Africa under the TCB's framework. Nanima finds that the Bill does not properly provide a satisfactory mechanism to evaluate evidence in criminal cases before it is admitted, and therefore does not safeguard against over-zealous 'prosecution' and ensure human rights protections for accused persons.

Mahlongonolo Thobane and Johan Prinsloo discuss 'bank associated robberies' - robberies (or attempted robberies) of cash that are committed against a bank client while en route to or from a bank or ATM. A relatively unknown phenomenon in public discourse on crime in South Africa, these robberies are of particular concern to the banking industry and criminal justice practitioners owing to their violent, traumatic nature and dramatic increase that put the general public at risk. Thobane and Prinsloo discuss the dynamics of bank associated robbery and its interrelationship with the so-called trio crimes of home invasions and robbery, business robberies and vehicle hijacking. They argue that these crimes increase perceptions about the violent nature of crime in South Africa and its increasing incidence, which place a huge burden on the criminal justice system.

Nicole van Zyl considers whether evidence of sexual grooming influences the decisions of South African courts when passing sentence on offenders who have been found guilty of sexual assault or rape of children. The article addresses three themes in the sentencing of these cases - the lack of violence, the apparent consent of a child under 12, and the appropriateness of correctional supervision as an alternative to custodial sentencing - and examines whether or how the characteristics of sexual grooming form part of these decisions. The article argues that evidence of 
grooming should play a more important role in sentencing decisions, providing context on the nature and impact of the crime that the court is asked to consider.

Elrena van der Spuy reviews Anneliese Burgess's book, Heist! South Africa's cash-in-transit epidemic uncovered, published in 2018 by Penguin Random House. She concludes that the book is 'riveting and troubling reading' that brings a 'disciplined inquiry to a complex issue of organised criminality' through an examination of 10 case studies. Van der Spuy lauds Burgess's work for its robust data gathering, its detailed portrayal of the actors and groupings involved in heists, their modus operandi and their justifications for engaging in the so-called seductions of crime. Van der Spuy concludes that Heist! sheds light on the connections between the illicit and licit, and the interplay of structure and agency that enables this kind of criminality.

Finally, this edition's On the Record presents a conversation between Nicolette Naylor (Director, Ford Foundation for Southern Africa) and Sibongile Ndashe (Executive Director: The Initiative for Strategic Litigation in Africa) on the role of the law in responding to sexual harassment in the workplace.

\section{Notes}

1 M Judge, 'Watch where you put your hands, oaf!' Mail \& Guardian, 31 August 2018, https://mg.co.za/article/2018-08-31-00-watchwhere-you-put-your-hands-oaf (accessed 24 September 2018).

2 Marikana Commission of Inquiry, Written submissions of the South African Human Rights Commission regarding 'phase one', 29 October 2014, 474. 